\title{
UNDERSTANDING ISAIAH BERLIN AS A HISTORIAN OF IDEAS: Lessons Learned for Muslim Scholars in Indonesia
}

\author{
Kamaruzzaman Bustamam-Ahmad \\ Universitas Islam Negeri Ar-Raniry, Aceh \\ Email: kamaruzzaman@ar-raniry.ac.id
}

\begin{abstract}
This article discusses the figure of Isaiah Berlin, a philosopher who studies the history of ideas in the West. Berlin has carried out the development of ideas in the West in his works. This article discusses the significance of ideas in the study of philosophy by looking at Berlin's experience. It can be argued that the study model from Isaiah Berlin can be used as a model for studying ideas by Muslim scholars in Indonesia. In this country, Muslim scholars tend to neglect the study of ideas, significantly developed in the 1990s. Through a bibliographical study of the works of Isaiah Berlin, this article presents the intellectual foundations of Berlin in reconstructing philosophical concepts. It is argued that Muslim scholars in Indonesia should return to more studies of ideas or thoughts in society.
\end{abstract}

Keywords: Isaiah Berlin, Historian Ideas, Muslim Scholar, Oxford Philosophy, Analytic Philosophy

DOI: https://doi.org/10.20414/ujis.v25i2.471

\section{Introduction}

THIS ARTICLE aims to introduce Isaiah Berlin to Islamic studies scholars in Indonesia. In the study of Islamic studies or Islamic philosophy, there is no study on Isaiah Berlin, both by Muslim and Western scholars. ${ }^{1}$ However, in philosophical studies in the West, Isaiah Berlin has only recently been studied by scholars on the history of ideas in the West. Therefore, the absence of Isaiah in the study of philosophy, because this figure appeared in recent years when Henry Hardy began editing all of Isaiah Berlin's works. ${ }^{2}$ In

\footnotetext{
${ }^{1}$ See, for example, Seyyed Hossein Nasr and Oliver Leaman, History of Islamic Philosophy (New York: Routledge, 1996).

${ }^{2}$ Henry Hardy, In Search of Isaiah Berlin: A Literary Adventure (London: I.B. Tauris, 2018).
} 
addition, Isaiah Berlin did not focus his studies on the existence of philosophy in the Islamic world.

I have tried to introduce Isaiah Berlin to readers in Indonesia. ${ }^{3}$ Although I do not have a background in philosophical studies, Berlin's ideas have, at least, made an impact in the study of the social sciences and humanities. This last factor caused me to realize that in developing research at PTKIN, it is necessary to strengthen a solid knowledge base when the social and humanities approach becomes the research agenda among lecturers at PTKIN campuses in the archipelago. For example, Isaiah Berlin was a mentor to Charles Taylor, a philosopher from Canada. Taylor has written on the figure of Hegel, and some of his work has influenced Western scholars. However, Isaiah Berlin instead discusses another figure not as well known as Hegel, namely Herder. ${ }^{4}$ Hegel had a relatively strong impact on Western researchers, who researched the Eastern World, and Indonesia was no exception. I have tried to explore the implications of Hegel's philosophical thinking after comparing him with the figure of Hamzah Fansuri ${ }^{5}$ This implies that although Berlin's focus is not on Hegel, his studies of Western philosophers have had an impact on how the West views the East.

This article intends to examine the figure of Isaiah Berlin (1909-1997), who was seen as one of the "abandoned philosophers" from Riga, Russia. ${ }^{6}$ When I started to understand the thoughts of Charles Taylor, a philosopher from McGill University, I began to consider the thoughts of Isaiah Berlin, who was also Taylor's mentor. When I was in Kuala Lumpur in 2012, while shopping for books at Kinokuniya KLCC, my spotlight was drawn to the display window of philosophy books, where Berlin books are sold.

${ }^{3}$ Kamaruzzaman Bustamam Ahmad, “Memahami Sejarah Intelektual Isaiah Berlin (1909-1997)," Esensia: Jurnal Ilmu-Ilmu Ushuluddin 17, no. 2 (2016): 279-98.

${ }^{4}$ Charlers Taylor, "The Importance of Herder," in Isaiah Berlin: A Celebration, ed. Margalit Edna and Margalit Avishai (London: The Hogarth Press, 1991), 4063.

${ }^{5}$ Kamaruzzaman Bustamam Ahmad, Islam Historis: Dinamika Studi Islam Di Indonesia (Yogyakarta: Jogja Bangkit Publishers, 2017).

${ }^{6}$ On Isaiah Berlin's name, see Arie M. Dubnov, Isaiah Berlin: The Journey of a Jewish Liberal (New York: Palgrave Macmillan, 2012), 19. 
I immediately bought a Berlin work entitled The Proper Study of Mankind. ${ }^{7}$ Therefore, when I read Isaiah's work, I did not understand the various concepts or figures that were the object of Isaiah's study. However, when comprehending Isaiah's works, I was forced to understand the history of thought or figures in the Western.

The scope of the field of study or work produced by Berlin is so deep that it demands another struggle in understanding Western thought in the 19-20 AD centuries. There are works of Isaiah that attempt to investigate the thinking of philosophers in the 17th and 18th centuries Berlin also produced a very comprehensive work on Karl Marx (1818-1883). ${ }^{8}$ Berlin's work on Marx was Berlin's first work as a historian of ideas. ${ }^{9}$ Not only that, one of Berlin's efforts was to criticize the Enlightenment Era in the West. $^{10}$

Isaiah's history of life as a Jew, born in Riga (now Latvia) in Russia, working intellectually in England at Oxford University, and being recognized as one of the world's foremost philosophers, encouraged me to examine him as a historian of ideas. It can be noted that the history of ideas can reconstruct a new understanding as a response to resistance to Western domination through the concept of the Enlightenment, which has alienated an entity of world civilization, namely the Jews. ${ }^{11}$ Some of Isaiah's ideas that have attracted the attention of scholars are the concept of liberty, in which he explains that there is positive liberty and negative liberty. Scholars often quote his work, entitled the Hedgehog and the Fox. ${ }^{12}$ Berlin also concerns the three areas

7saiah Berlin, The Proper of Study of Mankind: An Anthology of Essays, ed. Henry Hardy and Roger Hausheer (New York: Farrar, Straus and Giroux, 2000).

${ }^{8}$ Isaiah Berlin, Karl Marx, ed. Henry Hardy, 5th ed. (Princeton: Princeton University Press, 2013).

9Alan Ryan, "Foreword," in Karl Marx, by Isaiah Berlin, ed. Henry Hardy, 5th ed. (Princeton: Princeton University Press, 2013), xix.

${ }^{10}$ Isaiah Berlin, Three Critics of the Enlightenment, ed. Henry Hardy, 2nd ed. (Princeton: Princeton University Press, 2013).

${ }^{11}$ Isaiah Berlin, "The Origins of Israel," in The Power of Ideas, by Isaiah Berlin, ed. Henry Hardy (Princeton: Princeton University Press, 2013), 173-96.

${ }^{12}$ Isaiah Berlin, The Hedgehog and the Fox: An Essay on Tolstoy's View of History, ed. Henry Hardy, 2nd ed. (Princeton: Princeton University Press, 2013). 
where he lived his life, namely Russia, Jews, and the West. For the study of Russia, Berlin wrote Russian Thinkers ${ }^{13}$ and The Soviet Mind: Russian Culture Under Communism. ${ }^{14}$ As for Berlin's impressions of those around him, he worked at All Souls at Oxford University, edited by Henry Hardy in Personal Impressions. $^{15}$

\section{The Power of Ideas: Berlin's Legacy in His work}

Philosophers are sometimes behind significant events in the world. Concepts and theories produced by thinkers, writers, and philosophers sometimes become viruses for a society. The study of thought is not an empirical study related to social relations. Nevertheless, more than that, this study seeks to understand the concepts generated by the thinker when he responds to social situations while they are still alive. There are concepts from philosophers that are used when they have passed away. Therefore, never underestimate philosophers, who, day and night, are thinking discovering concepts or theories, which of course, involve a straightforward framework. In his writing about Two Concept of Liberty, Isaiah reminded never to underestimate a professor. The power of ideas, according to Berlin, are "philosophical concepts nurtured in the stillness of a professor's study could destroy a civilization." 16

Berlin's works show that as a historian of ideas, he produced works until his death on November 5, 1997, covering a wide range of ideas spread in Europe and America. Furthermore, Henry Hardy collected various personal letters, probably revealing much of Berlin as an intellectual and diplomat. Berlin is truly a scholar full of ideas on many philosophical issues. Therefore, it can be ascertained that the horizon of the work produced by Berlin

\footnotetext{
${ }^{13}$ Isaiah Berlin, Russian Thinkers, ed. Henry Hardy and Aileen Kelly (London: Penguin Books, 1994).

${ }^{14}$ Isaiah Berlin, The Soviet Mind: Russian Culture Under Communism, ed. Henry Hardy (Washington, DC: Brookings Institution Press, 2003).

${ }^{15}$ Isaiah Berlin, Personal Impressions, ed. Henry Hardy (Princeton: Princeton University Press, 2014).

${ }^{16}$ Isaiah Berlin, "Two Concepts of Liberty," in Liberty, by Isaiah Berlin, ed. Henry Hardy (Oxford: Oxford University Press, 2002), 167.
} 
compels us not to neglect any of his works. Henry Hardy has done a great job editing Berlin's works from several sources over the decades. Hardy met Berlin in 1972 as a student. According to him, he has worked editing Berlin works until 2015. However, the Berlin project started in 1990. ${ }^{17}$ Although Hardy retired in 2015, he remains an Isaiah Berlin Legacy Fellow at Wolfson at Oxford University. There are Berlin's lectures transcribed, retyped interviews, speeches that had to be corrected, and personal letters that were rearranged chronologically. In almost all of Berlin's edited works, Hardy describes the various stories behind the work he has edited. The discussion with Berlin is also interesting to read. Because of this, Hardy always lists Isaiah Berlin's works chronologically in each of his edited works. ${ }^{18}$ It can be said that almost all of Berlin's private lectures, essays, and letters have been edited by Hardy published in many book titles from the 1990s to 2015. Furthermore, there are contexts for understanding Berlin's works. The first is the context of Berlin works. This context means that Berlin's works were written since the end of World War I. He also witnessed how the Cold War was between the United States and the Soviet Union. Likewise, Berlin's authorship dates from the 16th to the 20th centuries. It can be understood that Berlin's works were a response to his belief in the power of ideas in historical episodes. When he wrote about Karl Marx, he did not want to be considered and claimed a Marxist. Despite his support for Israel, he still refused to occupy the position offered to him and his criticism of the Israeli government. When he chose England as a career place, he still had sympathy for what was happening in his native Russia.

Berlin's works contain information about the figures who influenced them, scholarly matters, and personal matters. Berlin writes about figures in several of his works; Berlin also touched on aspects of his relationship with the objects he had written about the history of ideas. He has met several written figures personally.

\footnotetext{
${ }^{17}$ Henry Hardy, "Editing Genius: The Isaiah Berlin Paper Project" (Oxford: Wolfson College Oxford, 2015), 4.

${ }^{18}$ Henry Hardy, "A Bibliography of Isaiah Berlin," in The Idea of Freedom: Essays in Honour of Isaiah Berlin, ed. Alan Ryan (Oxford: Oxford University Press, 1979), 271-88.
} 
This impression makes some Berlin writings able to discuss what is behind a text. These written works are supported by several figures, especially when he was a staff at the British embassy; as a lecturer at Oxford, he always met figures who influenced the history of ideas in the region on his trips to Russia and Israel. These advantages show that Berlin is not a scholar behind the desk but that he came out of the "safe zone" to obtain information embodied in several of his works as part of the history of ideas. Third, Berlin's works are more concerned with philosophical issues. Although his works are often categorized in the field as a history of ideas, a topic of study is profound and broad. Roger Hauser says, "At the heart of all Berlin's writings, there is a cluster of perennial philosophical problems." ${ }^{19}$ He also studied the Age of Enlightenment, intellectual traditions, and philosophical ways of thinking. There is also a Berlin work that examines the social sciences. When Berlin studied the philosophical tradition, he entered it into the heart of Romanticism.

It appears that Berlin is carrying out a study of the themes and schools of philosophy in the modern era, where Berlin understands how the impact of each existing philosophical school. Berlin made the understanding of philosophy for its main agenda in criticizing the philosophical schools in Europe. It seems that every school of philosophical thought has had a significant impact on every region through issues such as revolution, enlightenment, and the reconstruction of ideas. From the earliest paragraphs in "My Intellectual Path" and "My Philosophical Views," it is understandable that the academic experience at Oxford has indeed introduced Berlin to analytic philosophy.

Furthermore, in "My Intellectual Path," Berlin stated that the Vienna School influenced him..$^{20}$ This school of thought came from a group of philosophers at the University of Vienna (1922-1929). The group was led by Moritz Schlick who was Chair of the

\footnotetext{
${ }^{19}$ Roger Hausheer, "Introduction," in Against the Current, by Isaiah Berlin, ed. Henry Hardy (Princeton: Princeton University Press, 2013), xxxiv.

${ }^{20}$ Isaiah Berlin, "My Intellectual Path," in The Power of Ideas, by Isaiah Berlin, ed. Henry Hardy, 2nd ed. (Princeton: Princeton University Press, 2013), 2.
} 
Department of Philosophy of Inductive Sciences. ${ }^{21}$ The Vienna Circle is a group of scholars from the fields of natural science, social science, mathematics, and philosophy who discuss and develop the concept of positivism logic. ${ }^{22}$ Berlin wrote: "This school influenced me in the sense of being absorbed in the problem and theories which it generated, but I never became a true disciple." ${ }^{23}$ It appears that the Vienna Circle influences Berlin on two main aspects, namely how a problem is understood and the theoretical process. Berlin made this school of thought in understanding a problem and scientific theorization.

The main topic of the Vienna Circle is the nature of meanings related to truth and error, knowledge, and opinions that can be verified when an expression is expressed. ${ }^{24}$ In this case, Berlin called it verificationism. ${ }^{25}$ Apart from all expressions must be tested for truth, but for Berlin, these opinions are sometimes significant, without being tested first. This view is based on the study of natural sciences. Things that need to be verified are in the form of practical experience or what is known as "the world of sense." 26

Bernard Williams in his Introduction to Concepts and Categories writes:

Its members were concerned with the conditions of sentences having meaning, and with the connections between meaning and verification, where verification was construed in terms of sense-perception. Positivism both regarded natural sciences as the paradigm of knowledge and to a strict

${ }^{21}$ T.M. Soerjanto Poespowardojo and Alexander Seran, Filsafat Ilmu Pengetahuan: Hakikat Ilmu Pengetahuan Kritik Terhadap Visi Positivisme Logis, Serta Implikasinya (Jakarta: Kompas, 2015), 33.

${ }^{22}$ Stephen P. Schwartz, A Brief History of Analytic Philosophy: From Russell to Rawls (West Sussex: John Wiley \& Sons Inc., 2012), 46.

${ }^{23}$ Berlin, "My Intellectual Path," 2.

${ }^{24}$ See also Friedrich Stadler, "What Is the Vienna Circle? Some Methodological and Historiographical Answers," in The Vienna Circle and Logical Empericism: Re-Evaluation and Future Perspectives, ed. Friedrich Stadler (New York: Kluwer Academic Publishers, 2003), xi-xxiii.

${ }^{25}$ Berlin, "My Intellectual Path," 1. On this concept, see Isaiah Berlin, "Verification," in Concepts and Categories, by Isaiah Berlin, ed. Henry Hardy (Princeton: Princeton University Press, 2013), 15-40.

${ }^{26}$ Berlin, "My Intellectual Path," 3. 
empiricist view of science, seeing scientific theory in operationalist terms as a mere compendium and generator of actual and possible observations. ${ }^{27}$

In "My Philosophical Views," ${ }^{28}$ Berlin outlines themes that had been studied during his academic life. First, the initial contribution in the publication of philosophical studies. Berlin was interested in the logic of positivism and analytic philosophy that developed at Oxford. According to Berlin, the logic of positivism is "a movement directed against all forms of metaphysical or transcendental thought and expression. It is rigorously empirical and, in this respect, continues the central tradition of English philosophy, counting amongst its ancestor Berkeley, Hume, and Mill, and their most famous German disciple, Ernst Mach." 29

As for the Oxford philosophers, there is a view that states::

Oxford philosophers were much less interested in the philosophy of mathematics and philosophy of science than were the Cambridge philosophers and the logical positivists. Like their Continental existentialist counterparts, the Oxford philosophers took inspiration from literature, the arts, and politics. Several Oxford ordinary language philosophers went on to become important figures in other fields. Isaiah Berlin became a leading public intellectual and political thinker. ${ }^{30}$

Berlin emphasized that the term Oxford Philosophy is a meeting of young scholars in philosophy, in the Berlin room at All Souls College, in the 1930s. J.L. Austin raised this idea. This story of how Oxford Philosophy can be read in a Berlin essay entitled "J.L. Austin and the Early Beginnings of Oxford Philosophy. " The story of the discussion in the form of who influences whom, whose work should be studied, is presented by Berlin. However,

${ }^{27}$ Bernard Williams, "Introduction," in Concepts and Categories, by Isaiah Berlin, ed. Henry Hardy (Princeton: Princeton University Press, 2013), xxx.

${ }^{28}$ Isaiah Berlin, "My Philosophical Views," in Concepts and Categories: Philosophical Essays, by Isaiah Berlin, ed. Henry Hardy (Princeton: Princeton University Press, 2013), 277-83.

${ }^{29}$ Isaiah Berlin, "Logical Positivism," in Concepts and Categories: Philosophical Essays, by Isaiah Berlin, ed. Henry Hardy (Princeton: Princeton University Press, 2013), 305.

${ }^{30}$ Schwartz, A Brief History of Analytic Philosophy: From Russell to Rawls, 123.

${ }^{31}$ Isaiah Berlin, "J.L. Austin and the Early Beginning of Oxford Philosophy," in Personal Impressions, ed. Henry Hardy (Princeton: Princeton University Press, 2014), 156-76. 
from their discussion of several works starting from G.E. Moore to Wittgenstein, they came up with a thought, namely: "A sweeping anti-metaphysical empiricism was gaining converts rapidly. ${ }^{132}$ The relationship between Isaiah and Austin was very close. Michael Ignatieff noted that: "Austin was to become a central authority in Isaiah's life." ${ }^{33}$ The names involved in the discussion in the Berlin room were: Ayer, Berlin, Hampshire, Austin, Donald MacNabb, A.D. Woozley, and Donal Mackinnon. ${ }^{34}$ There are two groups based on empiricism and realism in this discussion. Their discussion was later also known as "a new generation of a rebellious empiricist at Oxford." ${ }^{35}$

When understanding Berlin's thought, the experience of discussion among the Oxford Philosophers in that space must be made a point where there is no room for metaphysical studies. Ignatieff notes that two main topics are being discussed: theories relating to the perception of personal identity and the possibility of knowing one's thoughts. ${ }^{36}$ These days, Berlin's intellectual journey in the field of philosophy is based on the logic of positivism and linguistic analysis. ${ }^{37}$ Second, freedom and determinism. Berlin said the free would issue had not been resolved. Because of this, some of his arguments can be found in his entitled essay "Historical Inevitability." ${ }^{38}$ Hausheer said that in this essay, "Berlin attacks deterministic theories which see history as obeying unalterable laws." ${ }^{39}$

${ }^{32}$ Berlin, 159.

${ }^{33}$ Michael Ignatieff, Isaiah Berlin: A Life (New York: Metropolitan Books, 1998), 84 .

${ }^{34}$ Ignatieff, 85.

${ }^{35}$ Naomi Choi, "Berlin, Analytic Philosophy, and the Revival of Political Philosophy," in The Cambridge Companion to Isaiah Berlin, ed. Joshua L. Cherniss and Steven B. Smith (Cambridge: Cambridge University Press, 2018), 37.

${ }^{36}$ Ignatieff, Isaiah Berlin: A Life, 85.

${ }^{37}$ Choi, "Berlin, Analytic Philosophy, and the Revival of Political Philosophy," 37.

${ }^{38}$ Isaiah Berlin, "Historical Inevitability," in Liberty, by Isaiah Berlin, ed. Henry Hardy (Oxford: Oxford University Press, 2002), 94-165.

${ }^{39}$ Roger Hausheer, "Introduction," in The Proper of Study of Mankind: An Anthology of Essays, by Isaiah Berlin, ed. Henry Hardy and Roger Hausheer (New York: Farrar, Straus and Giroux, 2000), xxvii. 
Berlin wrote an essay entitled "The Purpose of Philosophy " regarding the purpose of philosophy." Berlin's view of philosophy showed him to be a positivist. Berlin describes philosophy as "... is not empirical study; not the critical examination of what exists or has existed or will exist - this dealt with by common-sense knowledge and belief, and the method of natural sciences." ${ }^{40}$ Roger Hausheer said that: "As an empiricist and believer in rational methods, he was bound to sympathetic to their desire to sweep away theology and metaphysics, superstition, tradition, and blind authority." ${ }^{41}$ Thus, there is no story of the study of metaphysics in the intellectual experience of Berlin. ${ }^{42}$

\section{The Role of History of Ideas in Berlin's Thought}

Furthermore, one concept associated with Berlin is the history of ideas. Scholars say Berlin is a leading historian in explaining ideas, both from famous thinkers and vice versa. Avishai Margalit, for example, states: "Isaiah Berlin believed that ideas have power and that words are not 'mere words'. Ideas, at least some ideas, are 'matter from the heart' and not just from the head." 43 The legacy of thought from Berlin in the history of ideas is when he considers the history of ideas to answer the question: "Why and what should we want to know" ? ${ }^{44}$ The question implies that the idea has a powerful resonance. This power seizes the content of ideas that emanate from the human heart and head.

Joshua L. Cherniss, a scholar who studies Berlin's thoughts, ${ }^{45}$ says: "Isaiah Berlin was a fundamentally unsystematic

\footnotetext{
${ }^{40}$ Isaiah Berlin, "The Purpose of Philosophy," in Concepts and Categories, by Isaiah Berlin, ed. Henry Hardy (Princeton: Princeton University Press, 2013), 11.

${ }^{41}$ Hausheer, "Introduction," 2000, xxv.

${ }^{42}$ Choi, "Berlin, Analytic Philosophy, and the Revival of Political Philosophy," 17.

${ }^{43}$ Avishai Margalit, "Foreword," in The Power of Ideas, by Isaiah Berlin, ed. Henry Hardy, 2nd ed. (Princeton: Princeton University Press, 2013), xiii.

${ }^{44}$ Mark Lilla, "Foreword," in Against the Current: Essays in the History of Ideas, by Isaiah Berlin, ed. Henry Hardy, 2nd ed. (Princeton: Princeton University Press, 2013), xv.

${ }^{45}$ Joshua L. Cherniss, "Isaiah Berlin's Political Ideas: From the Twentieth Century to the Romantic Age," in Political Ideas in the Romantic Age: Their Rise and Influence of Modern Thought, by Isaiah Berlin, ed. Henry Hardy, 2nd ed. (Princeton:
} 
thinker. ${ }^{46}$ Berlin is an essayist, ${ }^{47}$ where the area and scope of Berlin's works are extensive. Joshua said that Berlin's works consisted of the very principles of the history of ideas, political theory, analytic philosophy, Russian literature, Soviet politics, historical philosophy, and social sciences. ${ }^{48}$ Joshua also stated that Berlin's thought was influenced when he was young, namely the intellectual culture of Oxford philosophy, German philosophy on history and social sciences, and debates about culture and politics during the war in England. ${ }^{49}$

However, these conditions do not reduce Berlin's position as a historian of ideas or philosophers of the 20th century. In Political Ideas in the Romantic Age, Joshua mentioned that this work made an essential contribution to the Berlin conceptualization process of liberty, his analysis of historical philosophy and criticism of determinism, and his views on the Enlightenment. ${ }^{50}$ Avery Plaw stated that this philosopher was a model that was an expert in the field of political thought, who made the connection between liberal politics and the political forces of pluralism, which challenged not only contemporary political theories in the West but also thought among scholars. leading, whether it is liberalcommunitarians or liberal-pluralists. ${ }^{51}$

In his introduction to The Power of Ideas, Avishai Margalit explains how Berlin relates to Marxism, Zionism, and the power of

Princeton University Press, 2014), xliii-xcii. Joshua L. Cherniss, A Mind and Its Time: The Development of Isaiah Berlin's Political Thought (Oxford: Oxford University Press, 2013).

${ }^{46}$ Cherniss, "Isaiah Berlin's Political Ideas: From the Twentieth Century to the Romantic Age," xliii.

${ }^{47}$ Lihat juga G. Patrick Lynch, "On Isaiah Berlin, or Why the Enemy of My Enemy Is Not Always My Friend," Revista de Instituciones, Ideas y Mercados, no. 60 (2014): 33-56.

${ }^{48}$ Cherniss, "Isaiah Berlin's Political Ideas: From the Twentieth Century to the Romantic Age," xliii.

${ }^{49}$ Cherniss, A Mind and Its Time: The Development of Isaiah Berlin's Political Thought, 1.

${ }^{50}$ Cherniss, “Isaiah Berlin's Political Ideas: From the Twentieth Century to the Romantic Age," xliv.

${ }^{51}$ Avery Plaw, "Isaiah Berlin's Pluralist Thought and Liberalism: A ReReading and Contrast With John Rawls" (Disertasi Doktor, Montreal, McGill University, 2001), 10. 
ideas. It explains that Berlin was very interested in Marx's thoughts. Alan Ryan noted that Berlin's first work on Karl Marx was "he first revealed his special talent as a historian of ideas - the discipline in which he enthralled his readers for the rest of his writing life." ${ }^{52}$ According to Avishai, the process of establishing the state of Israel is a "striking counterexample to the Marxist scheme of history." ${ }^{53}$

The power of ideas is above that of material. Material force is at the heart of Marx's thought. Berlin, according to Avishai, highly praises Weinman, one of the early initiators of Zionism, for being instrumental in establishing the state of Israel for the Jews. It can be understood that the effort to establish the state of Israel seems to be the result of the power of minds, which Berlin is a part of. ${ }^{54}$ Berlin criticized the ideas of Europe, which had marginalized the Jews. Therefore, it is crucial to understand Berlin's works on Zionism and Israel. In other words, Berlin's conceptual role in the establishment of the state of Israel was extraordinary. ${ }^{55} \mathrm{He}$ is often invited to Israel, apart from receiving awards, ${ }^{56}$ he also writes specifically about Judaism, Zionism, and Israel. ${ }^{57}$ By the Israeli government, Berlin was offered an important position in the country, but he refused. ${ }^{58}$

${ }^{52}$ Ryan, "Foreword," xix.

${ }^{53}$ Margalit Avishai, "Foreword," in The Power of Ideas, by Isaiah Berlin, ed. Henry Hardy (Princeton: Princeton University Press, 2013), xxiii.

${ }^{54}$ See Isaiah Berlin, "Chaim Weizemann," in Personal Impressions, by Isaiah Berlin, ed. Henry Hardy (Princeton: Princeton University Press, 2014), 57-96. Isaiah Berlin, "Chaim Weizmann's Leadership," in The Power of Ideas, by Isaiah Berlin, ed. Henry Hardy, 2nd ed. (Princeton: Princeton University Press, 2013), 227-37.

${ }^{55}$ Berlin, "The Origins of Israel."

56 Isaiah Berlin, "Epilogue: The Three Strands in My Life," in Personal Impressions, by Isaiah Berlin, ed. Henry Hardy, 3rd ed. (Princeton: Princeton University Press, 2014), 433-39.

${ }^{57}$ Isaiah Berlin, "Jewish Slavery and Emancipation," in The Power of Ideas, by Isaiah Berlin and Henry Hardy (Princeton: Princeton University Press, 2013), 197226.

${ }^{58}$ Hardy, “Editing Genius: The Isaiah Berlin Paper Project," 3. 
Thus, to understand Berlin's idea, his study of Karl Marx as written in his Karl Marx and other writings on Marx, ${ }^{59}$ has meaning in understanding Berlin's attitude towards Israel. Furthermore, it is said that Berlin started his career as a professional philosopher who was engaged in knowledge theories. However, he did a study of Karl Marx. Berlin began to enjoy the studies of Marx and social problems, political theory, and historical philosophy. ${ }^{60}$ According to Berlin, Marx was a typical social theorist in the 19th century. ${ }^{61}$ Therefore, it seems that through the study of Karl Marx, Berlin began to approach the study of social science. Marx was indeed one of the social science thinkers who greatly influenced the Soviets. What was going on in the Soviets was never separated from the ideas of Marx. ${ }^{62}$

Furthermore, in the soul and mind of Berlin, three traditions have influenced him and his works: Russian, English, and Jewish. As for Russia, Berlin made it an exciting place to study ideas. Russia is the best country to learn about the power of abstract ideas. ${ }^{63}$ According to Berlin, his concepts of history and society have identified him as "Russian origins." ${ }^{64}$ The significant

${ }^{59}$ Isaiah Berlin, "The Philosophy of Karl Marx," in The Power of Ideas, by Isaiah Berlin, ed. Henry Hardy (Princeton: Princeton University Press, 2013), 13952. Isaiah Berlin, "Benjamin Disraeli, Karl Marx and the Search for Identity," in Against the Current, by Isaiah Berlin, ed. Henry Hardy (Princeton: Princeton University Press, 2013), 317-60. Isaiah Berlin, "Marxism and International in the Nineteenth Century," in The Sense of Reality: Studies in Ideas and Their History, by Isaiah Berlin, ed. Henry Hardy (New York: Farrar, Straus and Giroux, 1997), 11667.

${ }^{60}$ Cherniss, "Isaiah Berlin's Political Ideas: From the Twentieth Century to the Romantic Age," xlv.

${ }^{61}$ Isaiah Berlin, "Political Ideas in the Twentieth Century," in Liberty, by Isaiah Berlin, ed. Henry Hardy (Oxford: Oxford University Press, 2002), 77.

62 Franz Magnis-Suseno, Dalam Bayang-Bayang Lenin: Enam Pemikiran Marxisme Dari Lenin Sampai Tan Malaka, 3rd ed. (Jakarta: Gramedia, 2016). Franz Magnis-Suseno, Dari Mao Ke Marcuse: Percikan Filsafat Marxis Pasca-Lenin (Jakarta: Gramedia, 2013).

${ }^{63}$ Berlin, "Epilogue: The Three Strands in My Life," 433. Lihat juga Strobe Talbot, "Foreword," in The Soviet Mind: Russia Culture Under Communism, by Isaiah Berlin, ed. Henry Hardy (Washington, DC: Brookings Institution Press, 2003), xiv-xv.

${ }^{64}$ Berlin, "Epilogue: The Three Strands in My Life," 435. 
influence on Berlin was in England, the experience of mutual respect and tolerance. In this country, Berlin experienced academic freedom while at Oxford and has experience life since his arrival in 1921. Meanwhile, regarding himself as a Jew, Berlin states that this identity is very personal. He deliberately allowed his Jewish identity to reside in his soul. The experience of the bitterness of the Jews, of course, leaves an impression. Because of this, he criticized Enlightenment doctrines that had eroded sympathy for the emotional bonds between races and cultures that existed in the West. $^{65}$

Roger Hausheer said that Berlin had studied the main problems in human life, in particular human identity and values, associations and organizations, political theory, and practice. ${ }^{66}$ Berlin defended Jewish interests and criticized the basic ideas of communism, he also made great leaps in his theoretical philosophy. Berlin's concepts or views often provoke several debates, both in his life and after his death. ${ }^{67}$ In Berlin's works, some results of Berlin's correspondence with scholars have been published regarding some of the responses to his work. ${ }^{68}$

In one of his essays, Berlin said: "Historians are concerned with the discovery, description, and explanation of the social aspects and consequences of what men have done and suffered." ${ }^{\prime 69}$ In Against the Current, he examines the significant figures of the 17th century before and after the revolution in France (1789-1799). There are names such as Giambattista Vico (Italy, 23 June 1668-23 January 1744), Machiavelli (Italy, 3 May 1469-21 June 1572), Montesquieu (France, 18 January 1689 - 10 February 1755), Alexander Herzen ( Russia, 25 March 1806-21 January 1870),

${ }^{65}$ Berlin, 439.

${ }^{66}$ Hausheer, "Introduction," 2000, xxiii.

${ }^{67}$ Ian Harris, "Berlin and His Critics," in Liberty, by Isaiah Berlin, ed. Henry Hardy (Oxford: Oxford University Press, 2002), 349-64.

${ }^{68}$ Berlin, Three Critics of the Enlightenment, 490-515. Isaiah Berlin, The Crooked of Humanity, ed. Henry Hardy (Princeton: Princeton University Press, 2013), 30333. Isaiah Berlin, Against the Current: Essays in the History of Ideas, ed. Henry Hardy, 2nd ed. (Princeton: Princeton University Press, 2013), 449-66. Isaiah Berlin, Liberty, ed. Henry Hardy (Oxford: Oxford University Press, 2002), 336-44.

${ }^{69}$ Isaiah Berlin, Vico and Herder: Two Studies in the History of Ideas (London: Chatto \& Windus, 1980), xiii. 
Moses Hess (Germany, 21 January 1812 - 6 April 1876), Benjamin Disraeli (London, 19 April 1881), Karl Marx (Germany, 5 May 1818- 14 March 1883), George Sorel (France, 2 November 1847 - 29 August 1922). Meanwhile, in Freedom and Its Betrayal, Berlin examines six European philosophers who are considered to be "the authoritarian legacy," ${ }^{\prime 70}$ namely: Claude Andrien Helvetius (France, 31 January 1715 - 26 December 1771), Jean-Jacques Rousseau (28 June 1712 - 2 July 1778), Johann Gottlieb Fichte (Germany, 19 May 1762 - 27 January 1814), Georg Wilhelm Friederich Hegel (Germany, 27 August -14 November 1831), SaintSimon (France, 17 October 1860 - 19 May 1825) ), and Joseph Maistre (France, 1 April 1753 - 26 February 1821). Apart from these names, Berlin also studied J.G. Hamann (27 August 1730 - 21 June 1788).

From the study of the philosophers examined by Berlin, it appears that he was indeed a historian of ideas presenting thought before and after the French Revolution. Not only that, but Berlin also presented thinkers in Russia in Russian Thinkers and The Soviet Mind. Apart from the name Herzen, in two books on intellectual development and art in Russia, the following names are also found: Tolstoy, Vissarion Belinsky, Bakunin, Akhmatova, Pasternak, Osip Emilievich Mandel'stha, and others. While a diplomat in Britain, he also wrote about scholars and political figures from Britain, the United States, and Israel. ${ }^{71}$ It is not surprising that when we turn to the pages of Berlin's work, the various ideas developed in Europe, the United States, and Israel are presented as a history of ideas.

Furthermore, due to Berlin's expertise in presenting the thoughts of figures, Hermione Lee mentioned Berlin as a political philosopher. Hermione Lee pointed out that:

Isaiah Berlin was a political philosopher, a historian of ideas ...a biographer, a narrator of lives. He believed in genius and in the power of individuals to change and influence history. He wanted to understand and describe how

\footnotetext{
${ }^{70}$ Enrique Krauze, "Foreword: Isaiah the Prophet," in Freedom and Its Betrayal, by Isaiah Berlin, ed. Henry Hardy, trans. Hank Heifetz (Princeton: Princeton University Press, 2014), xi.

${ }^{71}$ Isaiah Berlin, Personal Impressions, ed. Henry Hardy, 3rd ed. (Princeton: Princeton University Press, 2014).
} 
exceptional people behaved, thought, and affected the world. He was fascinated by charisma and intellectual energy. ${ }^{72}$

Thus, when reviewing the concepts from Berlin, we first examine how Berlin deals with thinkers, which he then conceptualizes some concepts that influence to this day. Berlin describes the power of charisma and the intellectual energy of a character, where he is interested in studying the influence of an idea in society. Thus, in principle, Berlin's works are an attempt to understand Berlin's way of understanding other people. Roger Hausheer stated that

At the heart of all Berlin's writings, there is a cluster of perennial philosophical problems. The nature of self, will, freedom, human identity, personality and dignity, the manner and degree in which can be abused, offended against, insulted, and their proper boundaries ...transgressed; the consequence, both probable and actual, of failing to understand them for what they are, and above all of torturing them into conformity with conceptual systems and models which deny too much of their nature; the distinction between 'inner' human nature as opposed to 'external' physical nature, and basic categories and methods proper to their investigation ... 73

In "Pursuit of the Ideal," as the first essay in this work, Berlin mentions that there are two quite important things that have shaped human history, namely: the development of science and technology and the development of an ideology that has changed the history of humankind. ${ }^{74}$

It must be acknowledged that these two things move people's lives everywhere. The development of science facilitates human life. As for ideology to make it is easier to organize people. Therefore, almost all historical narratives are often related to science and ideology. In an ideological context, Berlin writes: "...the great ideological storms that have altered the lives of virtually all mankind: the Russian Revolution and its

${ }^{72}$ Hermione Lee, "Foreword," in Personal Impressions, by Isaiah Berlin, ed. Henry Hardy, 3rd ed. (Princeton: Princeton University Press, 2014), xv.

${ }^{73}$ Hausheer, "Introduction," 2013, xxxiv.

${ }^{74}$ Isaiah Berlin, "The Pursuit of the Ideal," in The Proper Study of Mankind, by Isaiah Berlin, ed. Henry Hardy and Roger Hausheer (New York: Farrar, Straus and Giroux, 2000), 1. 
aftermath..." ${ }^{75}$ This statement implies that the Russian Revolution had such a powerful impact on people. Therefore, when understanding ideas that shape ideology, Berlin explains how human ideas are intertwined. Berlin writes that the concept of this idea is associated with the substance of ethics in political philosophy, as follows:

But it is as well to realize that this great movement began with ideas in people heads: ideas about what relations between men have been, are, might be, and should be; and to realize how they come to be transformed in the name of a vision of supreme goal in the minds of the leaders, above all of the prophets with their armies at their backs. Such ideas are the substance of ethics. Ethical thought consists of the systematic examination of the relation of human beings to each other, the conceptions, interests, and ideals from which human ways of treating one another spring, and the systems of value on which such ends of life are based. These beliefs bout how life should be lived, and what men and women should be and do, are objects of moral inquiry; and when applied to groups and nations, and indeed, mankind as a whole, are political philosophy, which is but ethics applied to society. ${ }^{76}$

\section{Lessons Learned for Muslim Scholars in Indonesia}

From the description of Berlin's intellectual experience, it seems that there are essential things to be noticed by Muslim scholars in Indonesia. First, Muslim scholars in Indonesia should start to adopt ideas or theories in developing their research and understand the academic tradition behind ideas as a theoretical framework, for example, from concepts taken from Western scholars. This method requires a way of working research to understand philosophical studies, not philosophy itself. The Berlin study above shows that ideas that develop in a society must be understood in-depth, as that society understands them.

Berlin provides an example of the power of ideas in a civilization. In Indonesia, the development of ideas has been going on for hundreds of years. The history of ideas among Indonesian Muslims needs to be studied and preserved. It is unfortunate if researchers come by using theories from outside to destroy the structure of ideas that have developed in society by employing

\footnotetext{
${ }^{75}$ Isaiah Berlin, "The Pursuit of the Ideal," in The Crooked Timber of Humanity, ed. Henry Hardy (Princeton: Princeton University Press, 2013), 1.

${ }^{76}$ Berlin, 1.
} 
Western standards. Berlin strongly rejected the existence of a uniform understanding of a society, which resulted from philosophers' thinking as part of the Enlightenment project. These ideas are Berlin's great legacy in its critique of the Enlightenment. There have been Muslim thinkers from the Arab region who applied the method by looking at their traditions, not by looking at the other practices, as seen from the works of Hassan Hanafi. ${ }^{77}$ Although since the 1990s, Hanafi has been well-known among Islamic scholars in this country, his legacy has not yet had an impact on Islamic studies in Indonesia.

The critical thinking model practiced by Berlin or Hanafi is no longer found in the research tradition at Islamic universities in Indonesia. During the last four years as a reviewer team at the Ministry of Religion, there has been no research proposal to analyze the tradition of ideas among Muslims in Indonesia. Therefore, the Berlin way of thinking is significant to disseminate to researchers. It's not just about understanding philosophy but understanding the tradition of philosophical thought. Berlin provides an example of how to analyze ideas with their academic background. He is a philosopher behind the desk and an essayist, diplomat, socialite, resource person for the BBC, who always meets with various social groups. From his encounters with multiple people, he then changed that experience as the material for his writings. This experience makes Berlin better known as a historian of ideas rather than a philosopher.

Secondly, an essential lesson for Muslim scholars in Indonesia is that Berlin once studied the past ideas, then he incorporated them into understanding the development of contemporary ideas. This academic effort may be strenuous for writers in Indonesia to emulate. Several scholars have conducted studies on the thought of Muslim thinkers in Indonesia. However, it is unlikely to be utilized the results of these thoughts to criticize the current situation in Indonesia. Usually, the study model is blamed for against the state policy, not why such a tradition of thinking exists

77 Ridho Al-Hamdi, “Hassan Hanafi's Occidentalism: Dismantling Western Superiority and Constructing Civilizational Equality," Epistemé: Jurnal Pengembangan Ilmu Keislaman 14, no. 1 (2019): 51-82. 
in society. Reformist Muslim in Indonesia know Abdurrahman Wahid, Nurcholish Madjid, Harun Nasution, Djohan Effendi, and so on in some of the works of Muslim scholars. Still, it isn't easy to find out how their ideas can analyze the current situation, where the community can be divided easily, if not pitted against each other. Berlin agrees with the establishment of the state of Israel, but he does not agree with the ways of the Israeli government. He showed his Jewish identity very broadly. But he also defends, in his writings, aspects of humanity. An understanding of the layers of ethics, morals, and values that strengthen the spirit of society is essential for Muslim scholars in Indonesia. The contribution of philosophy is to enlighten humanity to determine their views and behavior in dealing with various problems in their lives.

Islam in Indonesia has played an essential role in the intellectual development of society. However, these efforts did not lead to satisfactory results because philosophers did not apply the works of philosophy to the grassroots. The work of philosophy is only behind the desk, not in society. In the past, philosophers were with people in public spaces. His concern became general anxiety. Berlin tries to describe this in several of his works, on the experiences of society and individuals, in essays, which enlightened the reader when he examined it philosophically. One example is when he explores the tradition of intellectual and art in Russia. Researchers should not be a mouthpiece to only side with government interests. So far, the study of Muslim voices in society tends to blame society itself. Finally, some Muslim groups are sometimes one of the elements of the people in Indonesia who are accused if they determine their attitudes and behavior, not as the government wishes.

Berlin wrote this into a kind of philosophical work with many quotes and reflections from encounters with various community groups. Because of that, he had quite a strong sense of the object being written in his study. This effort needs to be practiced in academic work by Muslim scholars in Indonesia. Berlin's experience with the history of ideas and feelings derived from its social experience has made Berlin one philosopher who is often referred to in understanding contemporary problems. So, understanding the surfaces in a society that is easily divided is a 
philosophical task that Muslim scholars in Indonesia must study. In the past, Indonesian Muslim writers tried to relieve the people's suffering. Now the work has been neglected. So that academic work is no longer looking for answers to the problems faced by society, but for the academic career only. The Berlin experience, as shown in this article, can be used as a model as a starting point for restoring an intellectual spirit that favors the people.

Third, the study of philosophy for Islamic scholars in Indonesia must begin to explore the history of ideas in the archipelago. Berlin made the West the object of studying the history of ideas. Hasan Hanafi did so with the Arab region as the focus of his studies. In this case, Indonesian Muslim scholars can use Nusantara as their study area. ${ }^{78}$ The building on the history of ideas in the archipelago is still not well explored by researchers. They only still apply Western theories to review the science of the archipelago (Nusantaranology). ${ }^{79}$ I tried to use Isaiah Berlin's academic work as a foundation for studying Nusantaranology, where Islam and Muslims are the most critical aspects in this study. If previously I used social anthropology to build a study of Acehnology, now I try to use the history of ideas to study Nusantaranology. This strategy of employing the history of ideas may be an essential lesson for researchers from PTKIN campuses in Indonesia. My study of Berlin is still in progress. If before I introduce this figure, then in this article, I have tried to answer how Muslim researchers in Indonesia apply the Berlin idea in their research.

\section{Conclusion}

Berlin began his career as a lecturer in philosophy at Oxford University. He has then crowned a historian of ideas because he successfully combined history with philosophy. As far as this work is being studied, Berlin always starts with big ideas then combines them with philosophical thinking to support its

\footnotetext{
${ }^{78}$ Komaruddin Hidayat and Ahmad AF Gaus, Menjadi Indonesia: 13 Abad Eksistensi Islam Di Bumi Nusantara (Bandung: Mizan, 12006).

${ }^{79}$ Kamaruzzaman Bustamam Ahmad and Fitri Zulfidar Ibrahmi, "Construction of Social Sciences and Humanities Towards Nusantaranology," AlA'raf: Jurnal Pemikiran Islam Dan Filsafat 17, no. 2 (2020): 205-26.
} 
arguments. This tendency gives the whole narrative that Muslim scholars in Indonesia should understand Berlin as 'as it is. I have always seen that the lives of thinkers in the West are not entirely from many social and internal problems in their daily lives. It is scarce to see a philosopher living his life normally. Some issues occur around him, ranging from his family to his response to various events while they were alive. Berlin has no exceptions in that case. His academic career improved, but his childhood was bleak. The experience of the violence he saw has shaped how Berlin sees the world. Berlin also feels the bitterness of some of its sidekick experiences in Russia. This situation drives a great idea that underlies every event felt by Berlin. Therefore, this work grabbed my attention to understand the great concepts developed in Europe, where it became the object of Berlin studies during his lifetime.

It is emphasized that Muslim scholars in Indonesia can use the model of the history of ideas, as seen in the thought of Isaiah Berlin. In this study, it has been shown how powerful ideas exist in society. Although this is the work of philosophers, Berlin has simplified it into an exciting study for those interested in the study of ideas. Thus, scholars will remain in a position of neutrality and continue to think critically to defend society through reasoning against the understanding of ideas that develop in society. Therefore, this study model will help researchers continue studying community dynamics and analyzing them by looking at what people think, not by what theory should be used to analyze them. Understanding ideas in society or from great figures is a job to make the view that the power of ideas is very powerful, as Isaiah Berlin suggested.

\section{References}

Ahmad, Kamaruzzaman Bustamam. Islam Historis: Dinamika Studi Islam Di Indonesia. Yogyakarta: Jogja Bangkit Publishers, 2017.

- - - "Memahami Sejarah Intelektual Isaiah Berlin (1909-1997)." Esensia: Jurnal Ilmu-Ilmu Ushuluddin 17, no. 2 (2016): 279-98.

Ahmad, Kamaruzzaman Bustamam, and Fitri Zulfidar Ibrahmi. "Construction of Social Sciences and Humanities Towards 
Nusantaranology." Al-A'raf: Jurnal Pemikiran Islam Dan Filsafat 17, no. 2 (2020): 205-26.

Al-Hamdi, Ridho. "Hassan Hanafi's Occidentalism: Dismantling Western Superiority and Constructing Civilizational Equality." Epistemé: Jurnal Pengembangan Ilmu Keislaman 14, no. 1 (2019): 51-82.

Avishai, Margalit. "Foreword." In The Power of Ideas, by Isaiah Berlin, xiii-xxiv. edited by Henry Hardy. Princeton: Princeton University Press, 2013.

Berlin, Isaiah. Against the Current: Essays in the History of Ideas. Edited by Henry Hardy. 2nd ed. Princeton: Princeton University Press, 2013.

- - - "Benjamin Disraeli, Karl Marx and the Search for Identity." In Against the Current, by Isaiah Berlin, 317-60. edited by Henry Hardy. Princeton: Princeton University Press, 2013.

- - . "Chaim Weizemann." In Personal Impressions, by Isaiah Berlin, 57-96. edited by Henry Hardy. Princeton: Princeton University Press, 2014.

- - - "Chaim Weizmann's Leadership." In The Power of Ideas, by Isaiah Berlin, 227-37. edited by Henry Hardy, 2nd ed. Princeton: Princeton University Press, 2013.

- - - "Epilogue: The Three Strands in My Life." In Personal Impressions, by Isaiah Berlin, 433-39. edited by Henry Hardy, 3rd ed. Princeton: Princeton University Press, 2014.

- - - "Historical Inevitability." In Liberty, by Isaiah Berlin, 94165. edited by Henry Hardy. Oxford: Oxford University Press, 2002.

- - -. "Jewish Slavery and Emancipation." In The Power of Ideas,

by Isaiah Berlin and Henry Hardy, 197-226. Princeton: Princeton University Press, 2013.

- - . "J.L. Austin and the Early Beginning of Oxford Philosophy." In Personal Impressions, edited by Henry Hardy, 156-76. Princeton: Princeton University Press, 2014.

- - - Karl Marx. Edited by Henry Hardy. 5th ed. Princeton: Princeton University Press, 2013.

- - . Liberty. Edited by Henry Hardy. Oxford: Oxford University Press, 2002. 
- - . "Logical Positivism." In Concepts and Categories: Philosophical Essays, by Isaiah Berlin, 305-15. edited by Henry Hardy. Princeton: Princeton University Press, 2013.

- - - "Marxism and International in the Nineteenth Century."

In The Sense of Reality: Studies in Ideas and Their History, by

Isaiah Berlin, 116-67. edited by Henry Hardy. New York:

Farrar, Straus and Giroux, 1997.

- - - "My Intellectual Path." In The Power of Ideas, by Isaiah

Berlin, 1-28. edited by Henry Hardy, 2nd ed. Princeton:

Princeton University Press, 2013.

- - . "My Philosophical Views." In Concepts and Categories:

Philosophical Essays, by Isaiah Berlin, 277-83. edited by Henry

Hardy. Princeton: Princeton University Press, 2013.

- - - Personal Impressions. Edited by Henry Hardy. Princeton:

Princeton University Press, 2014.

- - - Personal Impressions. Edited by Henry Hardy. 3rd ed.

Princeton: Princeton University Press, 2014.

- - - "Political Ideas in the Twentieth Century." In Liberty, by

Isaiah Berlin, 55-93. edited by Henry Hardy. Oxford: Oxford University Press, 2002.

- - - Russian Thinkers. Edited by Henry Hardy and Aileen Kelly.

London: Penguin Books, 1994.

- - - The Crooked of Humanity. Edited by Henry Hardy.

Princeton: Princeton University Press, 2013.

- - - The Hedgehog and the Fox: An Essay on Tolstoy's View of

History. Edited by Henry Hardy. 2nd ed. Princeton: Princeton University Press, 2013.

- - - "The Origins of Israel." In The Power of Ideas, by Isaiah

Berlin, 173-96. edited by Henry Hardy. Princeton: Princeton University Press, 2013.

- - - "The Philosophy of Karl Marx." In The Power of Ideas, by

Isaiah Berlin, 139-52. edited by Henry Hardy. Princeton:

Princeton University Press, 2013.

- - - . The Proper of Study of Mankind: An Anthology of Essays.

Edited by Henry Hardy and Roger Hausheer. New York:

Farrar, Straus and Giroux, 2000. 
- - - "The Purpose of Philosophy." In Concepts and Categories,

by Isaiah Berlin, 1-14. edited by Henry Hardy. Princeton: Princeton University Press, 2013.

- - - "The Pursuit of the Ideal." In The Proper Study of Mankind, by Isaiah Berlin, 1-16. edited by Henry Hardy and Roger Hausheer. New York: Farrar, Straus and Giroux, 2000.

- - . "The Pursuit of the Ideal." In The Crooked Timber of Humanity, edited by Henry Hardy, 1-20. Princeton: Princeton University Press, 2013.

- - - . The Soviet Mind: Russian Culture Under Communism. Edited by Henry Hardy. Washington, DC: Brookings Institution Press, 2003.

- - - Three Critics of the Enlightenment. Edited by Henry Hardy. 2nd ed. Princeton: Princeton University Press, 2013.

- - - "Two Concepts of Liberty." In Liberty, by Isaiah Berlin, 166-217. edited by Henry Hardy. Oxford: Oxford University Press, 2002.

- - - "Verification." In Concepts and Categories, by Isaiah Berlin, 15-40. edited by Henry Hardy. Princeton: Princeton University Press, 2013.

- - - Vico and Herder: Two Studies in the History of Ideas. London: Chatto \& Windus, 1980.

Cherniss, Joshua L. A Mind and Its Time: The Development of Isaiah Berlin's Political Thought. Oxford: Oxford University Press, 2013.

- - . "Isaiah Berlin's Political Ideas: From the Twentieth Century to the Romantic Age." In Political Ideas in the Romantic Age: Their Rise and Influence of Modern Thought, by Isaiah Berlin, xliii-xcii. edited by Henry Hardy, 2nd ed. Princeton: Princeton University Press, 2014.

Choi, Naomi. "Berlin, Analytic Philosophy, and the Revival of Political Philosophy." In The Cambridge Companion to Isaiah Berlin, edited by Joshua L. Cherniss and Steven B. Smith, 3152. Cambridge: Cambridge University Press, 2018.

Dubnov, Arie M. Isaiah Berlin: The Journey of a Jewish Liberal. New York: Palgrave Macmillan, 2012. 
Hardy, Henry. "A Bibliography of Isaiah Berlin." In The Idea of Freedom: Essays in Honour of Isaiah Berlin, edited by Alan Ryan, 271-88. Oxford: Oxford University Press, 1979.

- - . "Editing Genius: The Isaiah Berlin Paper Project." Oxford: Wolfson College Oxford, 2015.

- - - In Search of Isaiah Berlin: A Literary Adventure. London: I.B. Tauris, 2018.

Harris, Ian. "Berlin and His Critics." In Liberty, by Isaiah Berlin, 349-64. edited by Henry Hardy. Oxford: Oxford University Press, 2002.

Hausheer, Roger. "Introduction." In The Proper of Study of Mankind: An Anthology of Essays, by Isaiah Berlin, xiii-xxxvi. edited by Henry Hardy and Roger Hausheer. New York: Farrar, Straus and Giroux, 2000.

- - -. "Introduction." In Against the Current, by Isaiah Berlin, xxxi-lxxxiii. edited by Henry Hardy. Princeton: Princeton University Press, 2013.

Hidayat, Komaruddin, and Ahmad AF Gaus. Menjadi Indonesia: 13 Abad Eksistensi Islam Di Bumi Nusantara. Bandung: Mizan, 12006.

Ignatieff, Michael. Isaiah Berlin: A Life. New York: Metropolitan Books, 1998.

Krauze, Enrique. "Foreword: Isaiah the Prophet." In Freedom and Its Betrayal, by Isaiah Berlin, xi-xxii. edited by Henry Hardy, translated by Hank Heifetz. Princeton: Princeton University Press, 2014.

Lee, Hermione. "Foreword." In Personal Impressions, by Isaiah Berlin, xv-xxiv. edited by Henry Hardy, 3rd ed. Princeton: Princeton University Press, 2014.

Lilla, Mark. "Foreword." In Against the Current: Essays in the History of Ideas, by Isaiah Berlin, ix-xix. edited by Henry Hardy, 2nd ed. Princeton: Princeton University Press, 2013.

Lynch, G. Patrick. "On Isaiah Berlin, or Why the Enemy of My Enemy Is Not Always My Friend." Revista de Instituciones, Ideas y Mercados, no. 60 (2014): 33-56.

Magnis-Suseno, Franz. Dalam Bayang-Bayang Lenin: Enam Pemikiran Marxisme Dari Lenin Sampai Tan Malaka. 3rd ed. Jakarta: Gramedia, 2016. 
- - - Dari Mao Ke Marcuse: Percikan Filsafat Marxis Pasca-Lenin. Jakarta: Gramedia, 2013.

Margalit, Avishai. "Foreword." In The Power of Ideas, by Isaiah Berlin, edited by Henry Hardy, 2nd ed. Princeton: Princeton University Press, 2013.

Nasr, Seyyed Hossein, and Oliver Leaman. History of Islamic Philosophy. New York: Routledge, 1996.

Plaw, Avery. "Isaiah Berlin's Pluralist Thought and Liberalism: A Re-Reading and Contrast With John Rawls." Disertasi Doktor, McGill University, 2001.

Poespowardojo, T.M. Soerjanto, and Alexander Seran. Filsafat Ilmu Pengetahuan: Hakikat Ilmu Pengetahuan Kritik Terhadap Visi Positivisme Logis, Serta Implikasinya. Jakarta: Kompas, 2015.

Ryan, Alan. "Foreword." In Karl Marx, by Isaiah Berlin, xix-xxviii. edited by Henry Hardy, 5th ed. Princeton: Princeton University Press, 2013.

Schwartz, Stephen P. A Brief History of Analytic Philosophy: From Russell to Rawls. West Sussex: John Wiley \& Sons Inc., 2012.

Stadler, Friedrich. "What Is the Vienna Circle? Some Methodological and Historiographical Answers." In The Vienna Circle and Logical Empiricism: Re-Evaluation and Future Perspectives, edited by Friedrich Stadler, xi-xxiii. New York: Kluwer Academic Publishers, 2003.

Talbot, Strobe. "Foreword." In The Soviet Mind: Russia Culture Under Communism, by Isaiah Berlin, xi-xvii. edited by Henry Hardy. Washington, DC: Brookings Institution Press, 2003.

Taylor, Charles. "The Importance of Herder." In Isaiah Berlin: A Celebration, edited by Margalit Edna and Margalit Avishai, 4063. London: The Hogarth Press, 1991.

Williams, Bernard. "Introduction." In Concepts and Categories, by Isaiah Berlin, xxix-xxxiv. edited by Henry Hardy. Princeton: Princeton University Press, 2013. 